\begin{tabular}{lcr}
\hline & A N N A L E S \\
UNivERSitatis & MARIAE CURIE-SKŁODOWSKA \\
LUBLIN - POLONIA & 2019 \\
VOL. XXVI, 2 & SECTIOK & \\
\hline
\end{tabular}

Mazovian State University in Płock, Faculty of Humanities and Social Science

ARKADIUSZ ŁUKASZ FORDOŃSKI

ORCID ID: http://orcid.org/0000-0002-5825-7445

ARKADIUSZ LEWANDOWSKI

ORCID ID: https://orcid.org/0000-0002-8161-2257

\title{
Polish Media Debate on the Migration Crisis. The Case of Opinion-Forming Media
}

\begin{abstract}
The purpose of the present paper was: to specify the significance of the problem of the migration crisis in the Polish media debate as well as to point out similarities and dissimilarities in the manner of presenting (depending on a given narration applied) this phenomenon on the basis of two major, albeit ideologically distinct, weeklies, that is "Polityka" and "Do Rzeczy", with the said two news magazines actively participating in the above-mentioned debate. The paper reconstructs the narrations presented by the said opinion-forming weeklies referring to the migration crisis and the issues related thereto. We also analyzed to what extent the weeklies differed with respect to the scrutinized phenomenon. For the sake of analysis, we availed ourselves of the assumptions of the agenda-setting theory.

In our opinion, the conducted analysis allows for regarding the problem of migration crisis as a major area for opinion-forming activities of both weeklies. The respective editors of both weeklies put forward specific interpretations of social phenomena; and what is more, the suggested narrations, in a multi-faceted way, built a model for comprehending the events of European importance, with the said events perceived, on the one hand, as a threat to the Polish state ("Do Rzeczy"); on the other hand, as a challenge which demands Poland's participation in the European politics ("Polityka"). Each weekly, while referring to some argumentation aimed at the demonstration of its sole moral rightness, attempted to discredit the position of the other.
\end{abstract}

Key words: migration crisis, Polish media debate, securitization, cultural security 


\section{INTRODUCTION}

The debate over migration crisis played an exceptionally important role in Polish politics. The peak of this crisis fell on the period of electoral campaigns before the presidential and then parliamentary elections of 2015, which made the respective positions held by particular parties as well as their ability to guess public mood with respect to this vital issue have a direct bearing on their respective results of the elections. It was 2015 that brought the alteration of political power in Poland: the presidential election was won by Andrzej Duda, a candidate of Law and Justice (Prawo i Sprawiedliwość), and it was this party with its electoral allies that proved to be victorious in the parliamentary election.

What exerted an important influence on the contours of the debate over migration crisis as well as on its results is - apart from the attitudes adopted by politicians the media, and in particular the so-called opinion-forming media, the coverages of which is the very subject of our analysis.

To serve the purpose of the present paper and the analysis of the media coverages included therein, we availed ourselves of the assumptions of agenda-setting theory (AST) by Maxwell McCombs [2014], with the latter theory having become in recent decades one of the most significant paradigms for researching mass media and communication [Dearing, Rogers 1996: 9; Jennings, Miron 2004; Nowak 2016 : 11; Walgrave, van Aelst 2006: 88].

When we conceive the scrutinized debate in terms of the framework suggested by McCombs we try to verify with what sorts of attributes (or with which bundles of attributes) the issue of migration crisis was connected (persuasive influence) [Nowak 2016: 13-15]. Referring to Ewa Nowak [2013: 7; 2016: 16], we can state that the use of AST in this context was supposed to enable the understanding of the way in which the weeklies provided their readers with the idea of how migration crisis-related issues should be linked to specific sub-problems. In other words, both weeklies simply suggested the ways of how to "conceive" them [McCombs 2014].

We also hold the opinion that at this point what should be mentioned is the concept of securitization by which we shall understand the process in which the very fact of a particular problem being given the semiotic label of "security" makes the very problem actually a part of the security-related issues and a part of the internal logic thereof. This means that a given issue, which belongs to the domain of a political debate or standard politics, acquires an extraordinary dimension (enters the realm of extraordinary politics), that is the realm of security [Fijałkowski 2012; 2013: 91]. To put it plainly, what we shall understand by the concept of securitization is the inclusion of particular issues in the realm of internal security and the exclusion thereof from it. The essence of securitization is then an "intersubjective" process of constructing security within which threats are becoming "objective" not because they are such by nature but because they are recognized as such [Buzan, Hansen 2010: 32-33; Dyduch 2016: 377; Fijałkowski 2013: 92]. 
In thus delineated theoretical-methodological context, we would like to focus our attention on specifying the key points of argumentation by both parties to the dispute as well as on verifying whether the activities of both magazines can be described from the perspective of AST. The purpose of the present paper was to specify the significance of the issue of migration crisis in the media debate as well as to point out the similarities and dissimilarities in the manner of presenting (by virtue of a given narration applied) this phenomenon on the basis of two major, albeit ideologically distinct, opinion-forming weeklies, that is "Polityka" and "Do Rzeczy", both of which actively participated in the debate. What appears to be justified is that we shall narrow down our considerations to the year 2015 since it is crucial in terms of Polish migration policy.

In the paper there was made the qualitative analysis of content, which takes into account the occurrence (or the lack thereof) of characteristic content, which, however, appears infrequently. Its advantage is also the fact that it serves to examine the intentions of the sender of message and it takes heed of the context and circumstances of the formation of given contents [Szczepaniak 2012: 95-96]. According to the said method, what we are supposed to do is to "sensitively and «understandingly» investigate what is qualitatively - and not quantitatively or frequentially - outstanding in the text under scrutiny" [Palska 1999: 166].

\section{OPINION-FORMING WEEKLIES AS OPINION-FORMING MEDIA IN POLAND}

The criteria of opinion-forming by the media are the subject of controversy. The business entities, which monitor opinion-forming of given media, identify it with the indicator of a number of citations by other media. However, such an attitude may lead up to obtaining the results that do not account for the intuition of what opinionforming essentially is. Agnieszka Kula [2013: 32-33] points out that on the basis of a quantitative criterion, the ratings were formed in which tabloid press, being rather popular in Poland, was regarded as more opinion-forming than "Polityka", the weekly which after all contains multi-faceted analyses of social issues. So, in this case, what is worth noticing is the fact that the former more effectively introduces particular issues to a public debate than the latter, rather than the fact that the former is also more opinion-forming than the latter. Still, any analysis of opinion-forming based on quantitative factors should not be dismissed out of hand because it allows for noting the factors that only to a small extent depend on the researcher's judgement. At the same time, any analysis of this type gives us considerably more opportunities to make comparisons across various magazines at the same time. ${ }^{1}$ So, as to avoid absurd conclusions, while referring to quantitative data, one should couple it with

In the present paper, after Stanisław Kuśmierski [1997: 26], we assume that public opinion is a "dynamically changing state of awareness of large social groups, consisting of opinions and beliefs of 
qualitative criteria, including a profile of the reader, the role of which in the processes of forming public opinion may be the more conspicuous the greater part thereof will be a leader of disseminating opinions. Furthermore, quantitative data should be also supplemented with the characteristics of the messages transferred by the examined media (citing information will play a different role from the one of citing opinions).

Bearing in mind that the citation rate should not be the only criterion employed here, we can still indicate that the weekly magazines scrutinized in the present paper belonged - within the category they fall into - to the most frequently cited ones. The research indicates that "Polityka" in this respect occupied the third best position in Poland in 2015 (855 citations), whereas "Do Rzeczy" proved to be fourth best (806 citations) [IMM 2015].

Next to the citation rate, which definitely testifies to a certain aspect of opinionforming, one should also take heed of the criterion of sale, which indirectly evidences the ability of exerting an impact on public opinion [Kawa 2014: 10-11]. The sale of both selected weekly magazines makes them the most popular examples of this type in Poland. "Polityka" in the analyzed period and within the periods directly preceding and following it, occupied the second or third position in this respect; whereas "Do Rzeczy" ranked fifth [Kurdupski 2016a; 2016b].

Among the qualitative criteria measuring the role of both weeklies in Poland, one should point out that both of them attempt to maintain the image of magazines for intelligentsia which promote a certain ethos. It seems that what applies to both weeklies is that their readers are, which is quite typical when it comes to press, the people who cherish the beliefs which converge with the content presented in respective magazines. The complexity of presented materials gives us a reason to think that the readers identify not only with the presented opinions but also with the argumentation applied in particular disputes. Therefore, the authors who publish in both of the weeklies can often be regarded as the authorities for their readers [Zamojska 2012: 497-499]. Although with the increase in popularity of the Internet, the popularity of opinion-forming weeklies drops, the latter's restricted role of shaping public opinion does not happen to be fully proportional to the process of the Internet gaining in popularity. This is simply because this sort of weeklies presents much more complex contents and at the same time their target are the people with their education being higher than average, which means the people who are therefore endowed with greater abilities to shape the opinions of other people.

The choices of "Polityka" and "Do Rzeczy" stemmed not only from their position on the market but also from the fact that these weeklies represent the opposite poles in the major political disputes in Poland. Simultaneously, both weeklies, while being deeply involved in political debates, keep their distance from major political parties. For several decades, "Polityka" has been a major magazine in Poland raising

variable stability, with this state of awareness related to the issues usually arguable the solution of which exerts a direct or indirect impact on current or future social interests". 
socio-political issues. It is a leftist magazine sympathetic towards social democracy. This weekly normally promotes the ideas of equality, social progress and tolerance. It has been published since 1957. In the People's Republic of Poland, this weekly developed the long-standing reputation for presenting relatively independent opinions under the authoritarian political regime. Under the new regime after 1989, it maintained its important position in a pluralized media system [Kotras 2013: 91]. On the other hand, the weekly "Do Rzeczy" has been operating on the publishing market since 2013; however, this magazine, taking into account the editorial board, was a successor of the weekly "Uważam Rze", which in autumn 2012, underwent radical transformations in its personnel [Gądek 2012]. In the introductory article of the first edition of the weekly, its editor-in-chief, Paweł Lisicki, stated that it will represent a conservative-liberal world-view; whereas, pointing to its goals, he listed the defense of Christian Polishness, national memory and also the freedom of public debate and of entrepreneurship [Lisicki 2013: 2].

\section{ANALYSIS OF CONTENTS}

Polish debate over the migration crisis was marked by considerable dynamism. Its participants, including the above-mentioned weeklies, to some extent altered their respective positions as the situation at the borders changed, as the policies pursued by the most important political actors in Europe changed; and finally, as the beliefs held by public opinion in Poland and other European Union member states on that issue got clarified. This process is particularly noticeable in case of "Polityka", which started to gradually attribute still greater and greater significance to that issue. What is more, this weekly increasingly advocated the idea that Poland should show solidarity towards those European Union member states to which refugees and immigrants fled most numerously.

At first, the journalists of both weeklies dealt with the issue to a small extent. In this respect, they rather availed of the texts by their respective collaborators. In "Do Rzeczy", Piotr Kowalczuk [2015a: 80-81], being a correspondent of the Polish Radio (Polskie Radio) on a daily basis, focused on the phenomenon of gangs trafficking in persons, with the gangs having thrived with the increase in the number of migrants coming to Italy. ${ }^{2}$ In the above-mentioned article, he merely hinted at the fact that the migration issue is and will continue to be the challenge for the European Union and its member states. Furthermore, a major challenge are both

\footnotetext{
According to Kowalczuk, what, paradoxically, contributed to the aggravation of the problem was the Italian government program Mare Nostrum launched after the tragedy of 3 October 2013 (when about 400 refugees got drowned). Mare Nostrum Operation involved lending a helping hand by Italian naval ships and coastguards to virtually anybody in need. During that period, Italians rescued almost as many as 100,000 persons, which, as the author underlines, only encouraged the gangs to continue their actions [Kowalczuk 2015a: 80].
} 
the connivance on the part of such countries as Turkey and Greece towards illegal transport of persons across the Mediterranean Sea and the problematic cooperation of the European states with respect to solving the migration issue (not obeying the rules specified in the Dublin III Regulation) [Kowalczuk 2015a: 80-81]. "Polityka" noted the problem connected with the conquests of the self-proclaimed Islamic State. However, it was as early as April 2015 that Adam Szostkiewicz [2015b: 59-61] did not believe that among the challenges that Europe might face in this context there can be the exodus of refugees from the areas occupied by Islamic warriors. It was only after the European leaders took up the issue that became a cover story in "Polityka". What is interesting, Kowalczuk turned readers' attention to the growing phenomenon of migration and to the probability of its intensification, backing up his theses with the relevant statistical data. Kowalczuk [2015b: 13] claims that the actions taken by the EU proved to be unhurried and its response possibilities were negligible. As he estimated, what was also missing was goodwill:

The sad truth is that nobody wants these refugees. Angela Merkel emphasized that the ones fleeing to Italy should be carefully registered. And it was rightly said. Out of one hundred seventy thousand immigrants entering Italy last year, one hundred thousand vanished into thin air. There is no clue what they are doing, their whereabouts or names are unknown. Italy failed to deal with the problem. The Chancellor of Germany reminded the Italians, who complained about the predicament they were caught in, of the fact that actually it was Germany, Sweden and France that admit seventy five percent of refugees coming to the European Union [Kowalczuk 2015b: 13].

Therefore, Kowalczuk noticed the problem of the lack of information on immigrants as well as he emphasized that the difficulties related to mass immigration afflict not only the states that refugees enter at the moment of crossing the European Union borders. The editor did not object to straightforward actions taken against human smugglers; however, he pointed out the difficulties with the application thereof:

Their boats should be sunk still at Libyan ports before they manage to take passengers on board. It is supposed to be a copy of Atlanta Operation, which tamed Somali pirates. Yet, what is needed now is a mandate of the United Nations and the consent of (some) Libyan government, which is rather unreal. (...) For a time being, the Union is doing what it does best - it waits for events to unfold [Kowalczuk 2015b: 13].

According to Kowalczuk, the EU could not solve the problem by eliminating its causes since the latter were rather independent of the EU (Syrian Civil War, ongoing fights in African countries, Libyan civil war and the aggravation of criminality). Simultaneously, he underlined the fact that the situation of refugees, especially during their journey to Europe, is really tough; and Italy has problems not only with refugees and immigrants but also with the criminals benefiting from smuggling them and 
from extorting money which apparently serves to fund refugee protection. Defying political correctness, he said:

There is no good way out from this gloomy situation. Europe is unable to admit and feed the entire hungry Africa. On the other hand, the Union, and - practically speaking - Italy, fell prey to its own humanitarian principles, cynically exploited by smugglers: to come to aid at sea and to hear everybody that would apply for asylum. What is more, the refugees coming from the areas afflicted by war cannot be sent back home [Kowalczuk 2015b: 14].

As a result, he continued, this sort of aid proved to be an incentive for smugglers [Winiecki 2015b: 59-61]. ${ }^{3}$ To summarize, when writing about refugees, Kowalczuk meant the ones who emigrated not only because of war but also for political or economic reasons. The author observed that Poland, as compared to the European Union member states, was not distinguished by any special activities in this respect; and what is more, in his opinion, prior experience demonstrated that even a group of a dozen or a few dozen persons might pose a challenge to the state.

The fact that originally the attitude of "Polityka" towards the analyzed problem was not unambiguous was evidenced by yet another text, which referred to much longer and richer Australian experience with maritime migration in recent years. Jędrzej Winiecki noted that the actions taken by this state are recognized by the United Nations and some lawyers as a serious offence and he stated that the said actions infringe the international law. He pointed out, however, that the friendly policy towards refugees pursued by leftist governments holding power was verified by the latter themselves since it caused the major increase in the wave of refugees. This, in turn, contributed to maritime disasters and, at the same time, the great number of victims. According to the data cited by Winiecki [2015a: 59-61], under the regime of social democrats, 1,200 people got drowned attempting to enter Australia. In his view, Australia's unfriendly policy of "turning back boats" could not be compared with Europe due to its being bound by the international law. He stressed that the situation of the Australian society, after all based on immigrants, would rather suggest the benefits stemming from their inflow, especially in the situation when certain vision of a policy towards them was worked out.

"Do Rzeczy" sided with "Polityka" in its negative evaluation of the sluggishness and ineptitude of the EU in dealing with the migration crisis. It was already in April that the opinion expressed by Marek Magierowski appeared in "Do Rzeczy". According to this author, the European Union was blind to the problem. On the other hand, when the issue was ranked as a top priority in summer and there appeared the

There were more causes of the aggravation of the crisis on the part of the EU member states. In another text in "Polityka", Winiecki pointed out that what influenced the increasing wave of immigrants and refugees were leaky borders in the Balkan states [Winiecki 2015b: 59-61]. 
suggestion to distribute the refugees among the member states of the Community on the basis of obligatory quotas, the weekly - as represented by Jacek Przybylski - cast doubt on the reputed efficacy of this mechanism while pointing to the lack of instruments that would allow the European Community to control its application. Furthermore, Przybylski called it into question also for humanitarian reasons: "Why should it be the case that a family which, risking its life, attempted to flee to Germany or France, should be compulsorily settled in Poland or the Czech Republic?" [Przybylski 2015: 71-72].

The journalists of "Do Rzeczy" were stressing that the actions taken by the European Union political elites, as well as by the leaders of Western European states and media therein are motivated by political correctness. Oliver Bault [2015: 74-75] in his article Francja ślepnie raised the issue of liberal-leftist media which avoided identifying the migration issue with the criminality in France. Rafał Ziemkiewicz went as far as to say that leftist media in Western Europe "are getting insane" and that

(...) the elementary care about the security of citizens and about the operations of their respective economies burdened with social benefits and unemployment as well as the most natural fears are all subsumed under the category of 'fascism'; while the prudence of Poland, Hungary or the Czech Republic is condemned more ruthlessly than Putin's invasion of Ukraine has ever been [Ziemkiewicz 2015a: 18-19].

What is more, any attempt at criticizing the policy of admitting migrants is treated as racist behavior [Ziemkiewicz 2015a: 18-19]. Magierowski [2015: 22-23] noted that the most influential European politicians know that migration crisis is a major problem of contemporary Europe; however, they are "paralyzed" - they are unable to make any decision that would be considered politically incorrect. This, in turn, leads to the radicalization of anti-establishment political movements and grants to them a chance of political success.

It is worth pointing out that from May till the end of summer, the issue was not raised in "Polityka" at all; however, when the issue recurred, the editors of the weekly concurrently expressed their plainly unambiguous attitude towards it, which was in line with the attitudes expressed by the states of Western and Southern Europe. Therefore, the weekly suggested that the waves of migrants flowing into Europe are to be admitted and assimilated [Wójcik 2015: 8; Ostrowski 2015b: 9]. The issue was reflected upon not only from the angle of suggested and actually implemented solutions but also from the perspective of emotions it evokes. The "Polityka" columnist Ludwik Stomma [2015a: 103] hinted at the fact that public opinion in the USA and in European countries is becoming more and more insensitive to immigrants' and refugees' hardship. As he noted, the information on this humanitarian crisis is provided further and further away from newspapers' front pages. Due to the above, he made a claim that only particularly gruesome tragedies that occurred in the close vicinity of European societies still attract Europeans' attention: 
As many as seventy-one bodies found in a refrigerated lorry on the Austro-Hungarian border at least temporarily sparked some interest. What accounted for this was presumably the fact that Austrians first spoke of thirty rotting corpses. It was only after having counted the skeletons recovered from the amorphous human blob, that they recorded as many as seventy casualties. Thus, the peak of macabre was reached, which will be indeed hard to surpass. And that is why, any consecutive tragedies will merit only a small font [Stomma 2015a: 103].

Stomma [2015a: 103] pointed out that contemporary times are particularly tough for migrants, who cannot - in the way they could before - avail themselves of safe boats. Wealthy countries turn a blind eye to them, whereas the source of migrants' hardship can be, according to the author, sought in destabilizing policies pursued by the governments of European countries and the USA. According to the columnist, solidarity was missing also in Poles, who, when migrating to other countries in the past, encountered the openness on the part of the locals. According to Stomma, the reasons for this lack of empathy and responsibility for the actions taken in the past were attributed to xenophobia, chauvinism and racism, which were supposed to characterize the societies of wealthy countries the attachment of which to the notion of humanism was of merely declarative nature. In another text, he formulated the same sort of indictment against one of the most famous critics of the Islamization of France and Europe, namely the author of the then hotly debated novel Submission, Michel Houellebecq. Stomma [2015b: 96] stated that this French author has at his disposal a sophisticated technique and is apparently a talented writer, yet he recognized Houellebecq's claims as similar to the ones announced by the former MP Leszek Bubel, known for his racist and radical anti-Semitic publications.

Łukasz Wójcik [2015: 9-10] tried to convince his readers that since the people flowing into Europe are desperate, they should not be distracted by any physical obstacles and hence in this situation what is necessary is to introduce proper solutions allowing for our co-existence with them. In this situation, he spotted a ray of hope - he claimed that immigration will help Europe maintain its system of social security. However, referring to the estimates by Eurostat and the European Commission, at the same time, he pointed out that to realize the above-stated objective would require more immigrants than have come so far. He added that Slovakia, Poland and Hungary are countries which should take a special interest in immigrants' inflow due to the problem of ageing societies. Wójcik was also in favour of creating a common European asylum system. He mentioned that nowadays it is impossible to separate economic migrants from refugees (due to the conditions of the crisis), but in the future, there should be high expectations related to the latter group. He suggested that some social programs should be created for them (similar to American ones) and that they should be given European green cards - they would save money which could be spent not on paying human smugglers but rather on their own businesses. In this way, according to Wójcik, the European states could benefit from the latter scenario 
(Wójcik evoked the data showing that immigrants demonstrate a higher economic activity than the persons inhabiting for years the countries the immigrants enter).

As he argued, such a decision would reduce the strain on an asylum system overburdened with claims by the persons pretending to be Syrians just to acquire a right to stay in the EU. Wójcik estimated that this issue is all grist to populists' mill and that is why the government of Ewa Kopacz, being under pressure of - in its opinion - the xenophobic Law and Justice party - did not agree on the quota plan. The author argued that these actions do harm to Polish-German relations and hence have a bearing on the possibility of maintaining the sanctions the European Union imposed on Russia. In this situation, he also spotted the risk of Poland's exclusion from the Schengen Area [Wójcik 2015: 9-10]. The problem of skepticism of Visegrad Group countries towards the relocation of refugees was presented by Tomasz Maćkowiak [2015: 56-58] in his article entitled Parszywa czwórka, which was supposed to make reference to the reception of this position by the public opinion in Western and Northern European countries. Maćkowiak outlined the history of the Group and on this basis he stated that the current actions taken by its leaders are contrary to the purposes that the Group was founded for in the first place, i.e. familiarizing Western partners with the states of this region and presenting the latter as similar to the former. He defended the position that instead of accusing each other of disloyalty, including the recent Kopacz's expose (which stood in contrast to prior settlements), it is rather advisable to return to those original objectives. On the other hand, after Kopacz's government declared that it is in favor of allocating the quotas of refugees, there appeared the article in "Polityka" written by Marta Mazuś shedding light on the so-far possibilities of admitting refugees by Poland as well as presenting what had already been worked out in this respect. As Mazuś claims, there was still much to be done in this area. Therefore, Mazuś does not agree with the position presented by the representatives of the government who were trying to prove that the state institutions are ready to admit any number of refugees [Mazuś 2015b: 10-11]. ${ }^{4}$ While to the editorial board of "Polityka" the Visegrad Group's objection to the relocation program was the starting point for criticism, the journalists of "Do Rzeczy" suggested that what deserved such criticism was the fact that Polish authorities rather resigned from the dissenting view as far as this issue was concerned. Ziemkiewicz [2015b: 20] highlighted this issue through the lens of Germany's desire for hegemony in Europe and he pointed out that breaking the solidarity of the Group in this area was to serve mainly German purposes.

German actions connected with analyzed migration crisis constituted the essential element of the debate in both weeklies. The journalist of "Do Rzeczy", referring to the decision on admitting immigrants and refugees, evaluated it as the one divorced from the consideration of social cost of the actions taken; or else - as a pragmatic

4 The position adopted by the government was reported by its spokesperson - see: Cezary Tomczyk [2015] 
one. The former attitude was adopted by Piotr Semka [2015: 20-21], who believed that the dominant position and the dominant belief in Germany is that admitting immigrants will enrich and make the country's development more dynamic, while not causing any social conflicts. Maciej Szymanowski and Witold Repetowicz attempted to rationalize Merkel's position. While commenting on the relocation program, Szymanowski stated: "In this manner Germany will be able to carry out the selection of the most educated and promising immigrants, all the remaining part will be sent to other European Union member states, or deported" [Szymanowski 2015: 24]. Repetowicz, on the other hand, argued that the German policy of openness is essentially a policy of "getting cheap labour force and depriving poor countries of their respective specialists", and so it is a policy driven by an economic interest of the country. However, Repetowicz maintained that although the main assumption of the policy in question was rational, the inflow of immigrants proved to be more intensive than expected (due to - among other reasons - the official invitation issued by German authorities). The successive actions taken by the German Chancellor were evaluated highly critically by the journalist. He resorted to emotionally charged words: "Merkel decided to squeeze the unwanted surplus of immigrants into other EU member states" [Repetowicz 2015: 78]. In his article bearing a telling title Europa u stóp Sultana, the author also remarked:

18 October, Angela Merkel went to Turkey with the mission which ran counter to her so-far pursued policy towards migration crisis in Europe. The slogan Herzlich willkommen ("warm welcome") is to be replaced by the red light given by Turkey. However, it is difficult to treat this visit as something more but catastrophe. What is meant thereby is both the effects of the talks, and their respective time and context [Repetowicz 2015: 78].

Taking into account both the time and context indicated that, being driven by interests, the Chancellor was ready not to pay attention to the changes occurring in Turkey at that time (violating human rights, ruining democracy and creating a new political regime).

The issue of immigrant relocation was of interest also to "Polityka". Filip Gańczyk [2015: 46-48] tried to prove that although originally the initiative was not positively received by a major part of EU member states (in the meantime Merkel managed to form a strong international coalition opting for this solution), what became feasible was implementing the program with the use of political pressure exerted on the states which oppose such a solution. As a result, Poland and other Visegrad Group countries experienced negative consequences.

As for the German society's actions taken towards immigrants and refugees, "Polityka" presented this aspect more broadly than "Do Rzeczy". When demonstrating what social mood in Germany was evoked by the inflow of the immigrants, Gańczyk pointed out that the majority of Germans optimistically evaluate the possibility 
of dealing with the crisis and the media are marked by the openness to newcomers. He noted, however, that this phenomenon also arouses the opposition which, under specific circumstances, takes rather drastic forms. To confirm the above statement, Gańczyk cited the statistics illustrating the number of acts of aggression and violation of a legal order as a reply to the inflow of refugees and immigrants. He also made the point that under the harsh conditions of the camps, people who live there resort to violence, including violence against one another. Apart from the context of interpersonal relations and the actions taken by political parties, what was also important was the context of the needs of the home economy. The growing economy required new labor force regardless of whether it came to Germany as refugees or immigrants. However, under the conditions of the crisis, the state authorities were not in favor of the latter. Yet, this group was rather numerous - according to Gańczyk [2015: 48], the largest group flowing at that time to Germany were the citizens of Syria. However, the next three most numerous groups came from Kosovo, Albania and Serbia, respectively.

Other articles in "Polityka" presented more and more vivid examples of repercussions of the crisis in Germany. There were highlighted contrasting views and attitudes on the part of German society and politicians manifested during Oktoberfest [Krzemiński 2015: 120]; the efficiency of German civil society; and the fact that the actions taken by the authorities are unhurried and insufficient taking into account the seriousness of the problem [Gierak-Onoszko 2015: 54-56]. The information on the crimes committed by refugees was not missing either, the examples of riots or the cases of rape, including a rape case involving the volunteer workers [Krzemiński 2015: 120].

Both weeklies provided opposite answers to the question whether the crisis should be understood in terms of a clash between civilizations. Both of them also considered in this context the threat of terrorism. "Polityka" decisively repudiated the claim that the phenomenon of mass migration can be causally related to terrorism, whereas "Do Rzeczy" strongly supported this statement. Teresa Stylińska [2015: 79] from "Do Rzeczy", associating migration crisis with the Islamic state, wrote:

It was precisely a Libyan jihadist who, a few months earlier, threatened that if the West assaults them in Libya, they shall apply "the human weapon", i.e. they will flood Europe with immigrants. As the British and Italian press revealed, hundreds of Libyan boats will transport half a million people overseas. The arrival of such a large of number of strangers will cause protests and riots in Europe. And jihadists could easily blend in this mass of people.

On the other hand, Przybylski claimed that the share of terrorists in the overall number of immigrants is apparently about a tiny fraction. However, any potential terrorist attack launched by illegal newcomers might incite anti-immigrant sentiments and spark a violent conflict between the refugees from Arabic and African countries 
and the autochthons [Przybylski 2015: 71]. Kowalczuk [2015a: 81] perceived this situation in a similar way and indicated the consequences in the situation where there could be terrorists among refugees:

Italian services and media strike an alarming note $(. .$.$) - the Islamic state encour-$ ages its warriors to, due to the lack of adequate inspection, enter Italy on large boats and then spark off the holy war in entire Western Europe. If at least one out of a thousand newcomers (...), who vanished into thin air, is a jihadist, it means that there are about one hundred potential terrorists going about Europe.

So, the message of the weekly boiled down to the claim that however unjustifiable the accusations directed at the refugees might be, their massive inflow may contribute to the realization of the goals of the Islamic state. It may cause the destabilization of the social situation in Europe and allow the groups of its warriors to get through, which would enable terrorist attacks and would deprive the European Union societies of the sense of security. Against this background, what can be regarded as a radical position was the one expressed by Tomasz Terlikowski [2015: 74] in his paper Kościót i nowa inwazja barbarzyńców: "The successive assaults by Islamic immigrants, the threats posed by the Islamic state against Europe as well as the growing number of people trying to get through to the European Union make the problem of «the new invasion of barbarians» more and more significant".

Still, according to this author, the problem cannot be simply resolved by closing the borders because the threat is posed by the Islamic immigrants already inhabiting Europe as well as by their descendants - their goals are not limited to fighting for full civil rights because they have already acquired them. What they fight for is rather to replace these rights with the Sharia law [Ziemkiewicz 2015a: 19]. In this situation, the journalist associated with Catholic circles points to one proper, in his opinion, solution, i.e. returning to "the roots and values" [Terlikowski 2015: 75]. Wójcik approaches the problem from an entirely different angle. He calls into question the thesis that the European states should first admit the Christians from the Middle East for cultural reasons. He concluded that in terms of habits, they are closer to Muslims and the argument from cultural vicinity should rather count in favor of openness in admitting immigrants from Ukraine, which, in his opinion, is missing. On the other hand, referring to the perspective of religious community, he maintained that selecting the neighbor for religious reasons is against the spirit of the gospel. What is more, Pope Francis encourages openness towards newcomers. Therefore, the refugees should have been admitted regardless of the unfavorable experience connected with the influx of migrants to Europe, as noted by Wójcik. He claims that the solution to the problems in this respect was greater openness towards immigrants and making it possible for them to take up work. The emerging migrant ghettos in European cities developed to a large extent as a result of the policy pursued by the states which were for a long time keeping those newcomers in refugee camps [Wójcik 2015: 8]. 
The position held by "Polityka" on the issue of threats stemming from mass migration was not shaken by terrorist attacks. Shortly after a series of terrorist assaults, Artur Domosławski argued that associating the phenomenon of terrorism with the massive inflow of refugees is a "cognitive and ethical" fallacy:

When the politicians in Poland and the USA are getting hysterical using the slogans "we do not want refugees here", the president of France announces that his country is going to admit thirty thousand newcomers. It is because he understands that the casualties of the attack in Paris as well as refugees - the majority of them being Muslims - are the victims of the same murderous sect. He grasps well that the hostility expressed by Europeans towards Muslims implies the greater number of recruits for jihad, which means the implementation of the scenario anticipated by the so-called Islamic state Domosławski [2015: 48]. ${ }^{5}$

Domosławski acutely observed that the growing aversion towards Muslims translates into the greater polarization between them and the remaining societies of Europe. Still, it should be underlined that among the reasons why Muslims are open to the slogans proclaimed by jihadists, were not only bad experience of social ostracism but also the common religious beliefs which, to some extent, justify the use of violence. It should be noted that it was also Stomma who - rather emotionally - formulated the view similar to Domosławski's opinion: "This simple thought will not occur to those thick-headed individuals that if an adherent of Islam really wanted jihad and Quranic law in its bastardized form, he would not escape, risking his or her life, from the place where the said law already prevails" [Stomma 2015a: 103].

The issue which is of interest to us here was also considered in the context of national policy; however, this thread was taken up mainly in "Polityka", whereas in "Do Rzeczy", this issue was barely raised and the columns were rather dedicated to the politicians of the Law and Justice party who showed their reluctance for refugees to be admitted. "Polityka" was not simply confined to criticising the policy pursued by Kopacz's government, being originally reluctant to the relocation program, but rather expressly called for sticking to the very initiative of admitting refugees. Marek Ostrowski [2015a: 9] in his article Nie uchodzi nie pomóc, ${ }^{6}$ argued that what commits us to helping other European countries struggling with the migration crisis is precisely morality in the first place. He pointed to the European law, the need for preserving the Union solidarity, being vital from the Polish perspective. He referred to benefits - however controversial they might seem to be - stemming from multiculturalism.

5 See also: Ostrowski [2015b: 58-60]. Ostrowski considers the problem from the perspective of class conflict and he states that a source of conflicts between Arabic societies and the French society are mainly class inequalities and not religious motives. In this situation, the solution to the problem of radicalism should be enabling social advancement.

Untranslatable word play. In Polish, uchodzi and uchodźca share the etymon. The former, when negated, means "it is indecent", whereas the latter refers to a refugee. 
He pointed out that the biggest challenge related to this matter has a psychological aspect and that is why he urged not to stir social fears - in other words, he urged "not to incite". What is important, the editorial board added the information on some other occasion that Ostrowski's attitude towards this issue is simultaneously shared by the board itself [Mazuś 2015a: 19]. Stomma, on the other hand, indicated the inconsistencies in the argumentation on the part of the people opposing the idea of admitting immigrants and refugees into Poland. He stated that since the politicians of Law and Justice claim that one should not allow refugees to enter Poland for this reason that they themselves are unwilling to come here and they are bound to immediately leave the country once they enter, it goes against the thesis advocated by this Party that the arrival of refugees implies any danger. What the author regarded as their incorrect reasoning was the claim that an additional threat stems from the fact of family reunification, which was supposed to lead to a significant increase in the number of admitted persons. Stomma's point was quite the opposite. He claimed that when young Muslims are accompanied by their families, they will be less susceptible to radical slogans of Islamic fanatics [Stomma 2015c: 102].

A more universal argumentation in favour of a specific solution to a political dispute was presented by Domosławski, who made use of the data he collected during his visit in Kos. He argued that it is unjustifiable to claim that one should provide help to refugees but not to economic immigrants. He gave the examples indicating that the distinction between the two groups in some specific cases is questionable and added that the immigrants, being driven to cross the EU border mainly for economic motives, are often caught in such a predicament that it would be indecent not to help them [Domosławski 2015a: 101-105; 2015b: 46-48]. He also invoked some arguments making reference to various worldviews: liberal, alter-globalist and Christian one. ${ }^{7}$ Domosławski [2015b: 46-48] also referred to the distinction between moral and metaphysical guilt, ${ }^{8}$ as formulated by Karl Jaspers [1979]. Based on that distinction, he also recalled the thesis by Zygmunt Bauman and Witold Gadomski [2001], who claimed that in the days of globalization, the borderline between these types of guilt is effaced - under the present circumstances we are responsible for the people from distant corners of our globe just as much as we are responsible for our neighbors. According to the above-mentioned authors, Poles are responsible for refugees and immigrants because Polish troops were involved in military interventions in Afghanistan and Iraq. Finally, he warned against the possibility that indifference to the fate of people in other countries may be a cause of another genocide [Domosławski 2015b: 49].

It was also Szostkiewicz who referred, during Christmas, to the argumentation derived from Christianity [Szostkiewicz 2015a: 18].

We are answerable only to God for this sort of guilt. On Jasper's typology of guilt into political, criminal, moral and metaphysical one [see: Jaspers 1979: 152-153]. 
"Polityka" also signaled the problem of the increasingly xenophobic, and even racist, sentiments in Poland, the manifestation of which were to be the slogans propounded by nationalist and kibitzer circles as well as the case of two Egyptians who were beaten up by three Poles in Cracow - the perpetrators were probably motivated by chauvinism [Kołodziejczyk 2015: 15-16; Jakimowicz-Ostrowska 2015: 8].

\section{CONCLUSIONS}

To sum up, both magazines provided weekly coverage of the events related to the migration crisis. What gradually emerged in case of "Polityka" was a definitely favorable attitude towards the participation of the Polish state in providing help to immigrants through admitting them into the territory of our country, whereas "Do Rzeczy" consistently depicted this sort of action as a threat to Polish security.

Both weeklies noted the complexity of the situation - that fact that the problem applies to people in different situations, that is both refugees and economic immigrants. It was also observed that the solution to the problem will not be easy. Although it must be admitted that some of the texts in "Polityka", which indicated the prejudices against the inflowing people as the most considerable obstacle to overcome, treated the problem rather superficially. Both of the editorial boards presented a series of arguments to support the respectively preferred options of resolving the crisis but their journalists did not refrain from employing the means serving to stir up some emotions. What was obviously not missing in both weeklies were critical notes directed at politicians as well as state and European institutions. The worldview disparities between the weeklies made it the case that what was condemnable for one magazine was favored by the other one. Both magazines justified their respective positions referring to moral reasons and simultaneously accusing their opponent of fear, unreasonableness or, finally, putting economic or political interest above moral reasons. The common denominator of the narrations occurring in both weeklies was to treat, in the first phase of 2015, massive migration as the problem related to humanitarian aid, with the problem still being significant for the EU.

Analyzing the scrutinized issues from the perspective of AST, what becomes noticeable are the attributes that both weeklies related to the migration crisis. For "Polityka", the problem of relocating refugees was a matter of solidarity with other European countries; whereas for "Do Rzeczy", the problem was reducible to the issue of social relations and social cost. What is more, in "Do Rzeczy", the migration issue was subject to the process of securitization. It was because the relocation of refugees was associated with the clash of cultures or with a threat of terrorism.

The conducted analysis, in our opinion, enables to regard the problem of migration crisis as an important area for opinion-forming activities of both weeklies. The editorial boards of both "Polityka" and "Do Rzeczy" suggested quite specific 
interpretations of social phenomena. Furthermore, the presented narration, in a multifaceted way, built the model for understanding the events of the European range, capturing them, on the one hand, as a threat to the Polish state ("Do Rzeczy"), and on the other hand, as a challenge which demands Poland's participation in the European politics ("Polityka"). While referring to the argumentation aimed at proving their moral rightness, each weekly strived to discredit the position held by the other. Therefore, the fact that both weeklies were acting for the sake of the dominance of respective opinion-forming circles, the representatives of which they were, seems to be the right judgement.

\section{BIBLIOGRAPHY}

Bault, O. 2015. Francja ślepnie, "Do Rzeczy”, 22.06.

Bauman, Z., Gadomski, W. 2001. Tak zwana globalizacja, "Gazeta Wyborcza", 9.11.

Buzan, B., Hansen, L. 2010. The Evolution of International Security Studies, University Press, Cambridge.

Dearing, J.W., Rogers E.M. 1996. Agenda-setting. Communication Concepts 6, SAGE Publications Thousand Oaks.

Domosławski, A. 2015a. Ludy świata pukaja do bram, "Polityka", 14.09.

Domosławski, A. 2015b. Robinson patrzy na Piętaszka, "Polityka", 30.11.

Dyduch, J. 2016. Sekurytyzacja a europeizacja. Między teoria a praktyka, [in:] Europa. Idee, koncepcje, rzeczywistość. Księga dedykowana profesorowi Wiesławowi Bokajle, J. Juchnowski, P. Turczyński, R. Wiszniowski (eds.), Wydawnictwo Libron - Filip Lohner, Kraków, pp. 373-387.

Fijałkowski, Ł. 2012. Teoria sekurytyzacji i konstruowanie bezpieczeństwa, "Przegląd Strategiczny", no. 1, pp. 149-161, DOI: https://doi.org/10.14746/ps.2012.1.10.

Fijałkowski, Ł. 2013. Akt mowy i język bezpieczeństwa a konstruowanie globalnych zagrożeń (dyskursywne podejście do bezpieczeństwa), "Kultura - Historia - Globalizacja" no. 14, pp. 91-102.

Gańczyk, F. 2015. Trudna gościnność, "Polityka", 7.09.

Gądek, J. 2012. Czystka w "Uwarzam Że”. Odchodza Pawet Lisicki, Wildstein i Gabryel, http://wiadomosci. onet.pl/tylko-w-onecie/czystka-w-uwazam-rze-odchodza-pawel-lisicki-wildstein-i-gabryel/1hpmk (access: 23.05.2018).

Gierak-Onoszko, J. 2015. Serce po berlińsku, "Polityka", 9.11.

IMM. 2015. Najbardziej opiniotwórcze polskie media w 2015 roku, https://www.imm.com.pl/sites/default/ files/raporty/najbardziej_opiniotworcze_media_w_2015.pdf (access: 27.05.2018).

Jakimowicz-Ostrowska, I. 2015. Arabowie w Krakowie, "Polityka", 28.09.

Jaspers, K. 1979. Problem winy, "Etyka", no. 17, pp. 145-206.

Jennings, B., Miron, D. 2004. Theory and Research in Mass Communication, "Journal of Communication", vol. 54(4), pp. 662-704, DOI: http://dx.doi.org/10.1111/j.1460-2466.2004.tb02650.x.

Kawa, D. 2014. Polska prasa opiniotwórcza wobec Niemiec w latach 2001-2005, Wydawnictwo Adam Marszałek, Torun.

Kołodziejczyk, M. 2015. Każdy inny, wszyscy biali, "Polityka", 5.10.

Kotras, J. 2013. Dwa światy, dwie narracje. Retoryka tygodników opinii ,W sieci” i „Polityka”, “Acta Universitatis Lodziensis. Folia Sociologica" vol. 46, pp. 89-109.

Kowalczuk, P. 2015a. Biznes na przemycie żywego towaru, "Do Rzeczy", 16.02.

Kowalczuk, P. 2015b. Ludzka powódź, "Polityka", 27.04.

Krzemiński, A. 2015. Spotkanie światów. „Polityka”, 5.10.

Kula, A. 2013.O pewnych zasadach sztuki publicystycznej w prasie opiniotwórczej: temporalność i argumentacyjność, "Poznańskie Studia Polonistyczne. Seria Językoznawcza”, vol. 20, pp. 31-40. 
Kurdupski, M. 2016a. Sprzedaż tygodników w 2015 roku. Tele Tydzień liderem, w czołówce magazyny people, http://www.wirtualnemedia.pl/artykul/sprzedaz-tygodnikow-w-2015-roku-tele-tydzien-lideremw-czolowce-magazyny-people-top-54 (access: 23.04.2018).

Kurdupski, M. 2016b. Polityka wyprzedziła Newsweek Polska w 2016 roku. Wprost o 38 proc. w dót, http://www.wirtualnemedia.pl/artykul/sprzedaz-tyodnikow-opinii-w-2016-roku-wprost-ostro-w-dol (access: 23.04.2018).

Kuśmierski, S. 1997. Opinia publiczna. Wstęp do teorii, Wydawnictwo WSE, Warszawa.

Lisicki, P. 2013. Wracamy, "Do Rzeczy", 2.01.

Maćkowiak, T. 2015. Parszywa czwórka, "Polityka", 5.10.

Magierowski, M. 2015. Toast za zdrowie imigrantów, "Do Rzeczy", 21.09.

Mazuś, M. 2015a. Bilet bez miejscówki, "Polityka", 16.09.

Mazuś, M. 2015b. Uchodźcy, instrukcja obstugi, "Polityka", 28.09.

McCombs, M. 2014. Setting the Agenda: Mass Media and Public Opinion, Polity Press, Cambridge.

Nowak, E. 2013. Wstep, [in:] Agenda-setting w teorii i praktyce politycznej, E. Nowak (ed.), Wydawnictwo Uniwersytetu Marie Curie-Skłodowskiej, Lublin, pp. 7-12.

Nowak, E. 2016. Teoria Agenda Setting a nowe media, "Studia Medioznawcze", vol. 3, pp. 11-24.

Ostrowski, M. 2015a. Nie uchodzi nie pomóc, "Polityka", 14.09.

Ostrowski, M. 2015b. Schodami nie winda, "Polityka", 26.10.

Palska, H. 1999. Badacz społeczny wobec tekstu. Niektóre problemy analizy jakościowej w socjologii i teorii literatury, [in:] Spojrzenie na metodę. Studia z metodologii badań socjologicznych, H. Domański, K. Lutyńska, A.W. Rostocki (eds.), Instytut Filozofii i Socjologii Polskiej Akademii Nauk, Warszawa, pp. 161-176.

Przybylski, J. 2015. Strażnicy cywilizacji, "Do Rzeczy”, 6.06.

Repetowicz, W. 2015. Europa u stóp sultana, "Do Rzeczy", 21.09.

Semka, P. 2015. Utopia teutonica, "Do Rzeczy", 14.09.

Stomma, L.2015a. Niech tu nie ida, "Polityka", 7.09.

Stomma, L. 2015b. Ulegtość, "Polityka", 21.09.

Stomma, L. 2015c. Wróg bliski i daleki, "Polityka", 5.10.

Stylińska, T. 2015. Wtosi patrza na Trypolis, "Do Rzeczy", 5.10.

Szczepaniak, K. 2012. Zastosowanie analizy treści w badaniach artykułów prasowych-refleksje metodologiczne, "Acta Universitatis Lodziensis. Folia Sociologica", no. 42, pp. 83-112.

Szostkiewicz, A. 2015a. Święta Rodzina na uchodźctwie, "Polityka", 13.04.

Szostkiewicz, A. 2015b. Armia strachu, "Polityka", 20.04.

Szymanowski, M. 2015. Orban ratuje Wegry, "Do Rzeczy", 14.09.

Terlikowski, T. 2015. Kościót i nowa inwazja barbarzyńców, "Do Rzeczy”, 31.08.

Tomczyk, C. 2015. Rząd gotowy na każdą liczbę uchodźców, "Rzeczpospolita”, 18.09.

Walgrave, S., Van Aelst P. 2006. The Contingency of the Mass Media's Political Agenda Setting Power: Toward a Preliminary Theory, "Journal of Communication", vol. 56, pp. 88-109, DOI: https://doi. org/10.1111/j.1460-2466.2006.00005.x.

Winiecki, J. 2015a. Odsyłacz, "Polityka", 13.05.

Winiecki, J. 2015b. Zamknięci na oścież, "Polityka", 28.09.

Wójcik, Ł. 2015. Ci obcy, "Polityka", 7.09.

Zamojska, M. 2012. W poszukiwaniu autorytetu... Cechy poznawcze, wartości edukacyjne oraz konsekwencje społeczne funkcjonowania wywiadu-wyktadu obecnego w mediach drukowanych oraz przestrzeni internetowej, [in:] W kręgu historii politologii i edukacji. Studia i szkice dedykowane profesorowi Witoldowi Wojdyle, Z. Karpus, G. Radomski, M. Strzelecki (eds.), Wydawnictwo Naukowe Uniwersytetu Mikołaja Kopernika w Toruniu, Toruń, pp. 497-507.

Ziemkiewicz, R. 2015a. To najeźdźcy, nie uchodźcy, "Do Rzeczy", 14.09.

Ziemkiewicz, R. 2015b. Europejski zamach stanu, "Do Rzeczy", 21.09. 


\section{BIOGRAPHIES}

Arkadiusz Lukasz Fordoński, PhD in political science, specializing in the contemporary political thought, axiology of human rights as well as in political marketing and social communication. He is a lecturer at the Mazovian State University in Płock. E-mail: arekfordoński@wp.pl

Arkadiusz Lewandowski, a graduate of the University of Nicolaus Copernicus in Torun, a doctor of political science. A member of the staff of the Faculty of Humanities and Social Science of the Mazovian State University in Płock. The scientific interests of this researcher focus on: Polish party system, the contemporary political thought as well as on social and cultural security of the Republic of Poland. E-mail: a.lewandowski2@gmail.com 